\title{
IS EFFICIENT GOVERNMENT AN OXYMORON?
}

\author{
PAUL R. VERKUIL $\dagger$ \\ INTRODUCTION
}

One of the pubhic sector's most enduring dilemmas is how to improve the performance of government without jeopardizing the nature of the political structure. This quandary assumes more urgent dimensions at a time when the private sector has made stunning efficiency gains. In the last ten years, American business has reengineered itself to regain the competitive edge that many assumed had been lost permanently to Japanese and German industrial enterprises. Today, American workers are the most productive in the world. ${ }^{1}$ Although corporate downsizing inevitably has caused some dislocations, the output of American workers continues to grow impressively and the level of employment has stabilized. $^{2}$ American companies are again world-class producers of critical goods like computer chips, communications technology, and even automobiles. ${ }^{3}$ This success virtually compels a comparison between the productivity of the public and private sectors.

American government has had the opportunity to track these productivity gains in the corporate sector and initiate changes in management structure to achieve comparable gains. Yet despite rhetoric suggesting otherwise, ${ }^{4}$ the evidence of government action

$\uparrow$ President \& Chief Executive Officer, American Automobile Association (AAA); President Emeritus, College of William \& Mary. Mr. Verkuil is a senior fellow of the Administrative Conference of the United States and former chairman of the ABA Section on Administrative Law and Regulatory Practice. This Comment is based on remarks presented at a symposium on the National Performance Review held at Duke University School of Law on January 20, 1994.

1. See Sylvia Nasar, The American Economy, Back on Top, N.Y. TIMES, Feb. 27. 1994, § 3, at 1; see also Productivity $U p$ by $4.2 \%$ in the Last Quarter of '93, N.Y. TIMES, Feb. 9, 1994, at D2.

2. See Nasar, supra note 1 .

3. The Japanese now are referring to the United States respectfully as "Rising Sam" because of its remarkable industrial turnaround. See T.R. Reid, "Rising Sun" Meets "Rising Sam," WASH. POST, Feb. 10, 1994, at A1.

4. See Christopher Farrell et al., Rudy Revs up the Chainsaw, Bus. WK., Feb. 21. 
is not reassuring. The U.S. Postal Service, which is supposed to emulate the productivity standards of private enterprise, has had few productivity gains over the last twenty years. ${ }^{5}$ Government employment at all levels has remained steady at about $18 \%$ of the workforce over the same period, while private sector employment per firm has declined significantly. ${ }^{6}$ Recently, for the first time, the number of workers in local, state, and federal government (about 18 million) surpassed those in manufacturing, ${ }^{7}$ which is an embarrassing statistic. The number of civilian workers in the federal government has remained steady at almost $3 \%$ of the workforce, about twice the ratio in Japan and Germany, ${ }^{8}$ countries with similar social systems that are America's main competitors.

In light of this seemingly embedded employment ratio, can constructive critics offer any hope for the improvement of productivity in the public sector? President Clinton obviously thought so when he mcorporated "reinventing government" into his campaign platform, ${ }^{9}$ and when he instructed Vice President Gore to fulfill

1994, at 42 (describing New York Mayor Rudolph Giuliani's proposal to reduce the çity government's workforce by 15,000 ).

5. An inside study of the Postal Service indicates that "postal productivity peaked in 1978, showing a cumulative $8 \%$ increase, and generally has declined with some fluctuations since that time." Postal RATE COMM'N STAF, STUdy of U.S. Postal SERvice Productivity AND ITS MEASUREMENT iii (1990).

6. Of course, government workers could argue that they have assumed new duties in the last 20 years that could affect their productivity. This argument surely arises in the Department of Education, where staffing has not kept pace with new student financial aid programs. But the irony is that this problem has allegedly resulted in the loss of billions of dollars in defaulted loans. See Michael Winerip, In Managing Federal Money, Education Officials Fall Short, N.Y. TiMES, Feb. 3, 1994, at A1. Generally, turnover in government is slow. In the federal government, the turnover rate is $1 \%$ to $2 \%$ annually, whereas many major private corporations recently have reduced their workforces by hundreds of thousands. President Clinton has committed to reducing the federal civilian, nonpostal workforce by $12 \%$ (250,000 workers) over the next five years. See AL GORE, THE National Performance Review, CReating a Government that WORKS BetTer \& COSTS LeSS iii (1993) [hereinafter NATIONAL PerformanCE ReView].

7. See BUREAU OF LABOR STATISTICS, U.S. DEPARTMENT OF LABOR, EMPloYMENT AND EARNINGS 59 (Aug. 1992). See generally Paul R. Verkuil, Reverse Yardstick Competition: A New Deal for the Nineties, 45 U. FlA. L. REV. 1, 10 (1993) (arguing that the federal government must "right-siz[e]" its bloated bureaucracy). at 94 .

8. Martin Schram, How About a Musical Chairs Cabinet?, NEwSDAY, Oct. 1, 1992,

9. In his inaugural address, President Clinton spoke of having the courage to "reinvent America." USA TODAY, Jan. 21, 1993, at 1A. The reinventing government theme is now well entrenched. See infra notes 35-36 and accompanying text. In the National Performance Review, President Clinton announced his intentions "to redesign, to reinvent, 
that promise by conducting a National Performance Review (NPR).$^{10}$ This Comment critiques the NPR Report and an accompanying document, Improving Regulatory Systems. ${ }^{11}$ The overriding purpose of the NPR is to create a government that is more efficient or, in the words of the report, that "works better and costs less." "12 Many American businesses have met this challenge. It remains to be seen whether the federal government can emulate their successes.

\section{THE NPR IN CONTEXT}

The regulatory systems report was prepared by Jeffrey Lubbers, Research Director of the Administrative Conference of the United States (ACUS), and five career agency employees. ${ }^{13}$ Time constraints limited the amount of research and the level of innovation that the group pursued, but the project resulted in ten cogently presented recommendations to improve the regulatory process. These recommendations borrow from prior reports ${ }^{14}$ and from executive initiatives, including, not surprisingly, several from the Carter administration. ${ }^{15}$ Every report borrows from other sources, and there is certainly nothing wrong with referring to the work of the Carter administration, even from a nonpartisan perspective. By embracing deregulation, the Carter administration im-

[and] to reinvigorate the entire national government." NATIONAL PERformanCE REview, supra note 6 , at 1 .

10. National Performance Review, supra note 6.

11. See Office of the Vice PResident, accompanying Report of the National PERformance Review: Improving Regulatory SySTemS [hereinafter IMPROVING REGULATORY SYSTEMS].

12. National Performance Review, supra note 6 , at $i$.

13. See Jeffrey S. Lubbers, Better Regulations: The National Performance Review's Regulatory Reform Recommendations, 43 DUKE L.J. 1165, $1165 \mathrm{n \dagger}$ (1994).

14. See, e.g., id. at 1168-69 (noting that the regulatory systems report borrowed heavily from the CARNEGIE COMmission ON SCIENCE, TECHNOLOGY AND GOVERNMENT, Risk and The Environment: Improving Regulatory Decision Making (1993)). The chairman of the report, Douglas Costle, was head of the Environmental Protection Agency (EPA) under President Carter and chairman of the Regulatory Council.

15. For example, the proposed Interagency Regulatory Coordinating Group draws its inspiration from President Carter's Regulatory Council. See IMPROVING REGULATORY SYSTEMS. supra note 11, at 17-22. Its purpose is laudatory-to get agencies to work together. Failure to do so is a principal reason that government cannot improve its efficiency. President Clinton has incorporated the regulatory working group into the role of the Office of Management and Budget (OMB) in monitoring agency regulations. See Exec. Order No. 12,866. 58 Fed. Reg. 51,735, 51,739 (1993). 
plemented the concept of efficiency in government. Indeed, that administration's deregulation and regulatory review efforts were accepted and extended by the Reagan and Bush administrations. ${ }^{16}$

The current administration prefers to reform rather than to reduce government and to de-emphasize deregulation. Yet it is difficult to incorporate efficiency standards into existing regulations without relyimg on deregulation. ${ }^{17}$ One of the virtues of deregulation is the ease of assessing results; many of the costs government regulation imposes on the private sector can be quantified, and when deregulation occurs, there are ways to measure the benefits. ${ }^{18}$ Unfortunately, the administration apparently has disregarded the importance of measuring the results of its programs.

Measuring the benefits of improvements in government performance is necessary, though. In this regard, the regulatory systems report is deficient. As the corporate world has learned, measurement is the key to performance. Efficiency cannot be sustained without an effort to quantify improvements. Whether for lack of time or lack of consensus, the regulatory systems team

16. See Geoffrey P. Miller, From Compromise to Confrontation: Separation of Powers in the Reagan Era, 57 GEO. WASH. L. REV. 401, 411 (1989); GLEN O. ROBINSON. AMERICAN BUREAUCRACY: PUBLIC CHOICE AND PUBLIC LAW 107-08 (1991) (discussing problems in the Reagan administration's deregulation efforts).

17. Deregulation is efficient in two ways: It frees industries to compete, and it reduces the number of government agencies. One example is the airline industry, in which deregulation led to increased competition and the demise of the Civil Aeronautics Board. Another is AT\&T, the breakup of which created entirely new players in the communications field and succeeded in improving efficiency. The NPR Report does not mention deregulation, but it does advocate the use of government corporations in some areas (e.g., Federal Aviation Administration airport control). See NATIONAl PERFormance REVIEW, supra note 6 , at $60-61$. Whether that method is better than the pure free market alternative of deregulation is questionable. See Verkuil, supra note 7, at 3-5.

18. See, e.g., Roger F. Naill \& Sharon Belanger, Impacts of Deregulation on U.S. Electric Utilities, PUB. UTiL. FORT., Oct. 12, 1989, at 24 (modelling the potential benefits of alternative proposals for electrical utility deregulation); see also Robert W. Hahn \& John A, Hird, The Costs and Benefits of Regulation: Review and Synthesis, 8 YALE J. ON REG. 233 (1991) (discussing the advantages and disadvantages of various methods of quantifying the impacts of regulation and stressing the importance of such quantification).

Admittedly, however, debates continue over the extent of the benefits of competition in industries such as transportation and telecommunications. See Robert M. Hardaway, Transportation Deregulation (1976-1984): Turning the Tide, 14 TRANSP. LJ. 101, 102-07 (1984) (discussing the "Great Deregulation Debate" with regard to the transportation industry); Emerging Competitive Forces in International Communications: Sate/lites and Cables, 54 ANTITRUST L.J. 235, 248 (1985) (panel discussion) (observing that complicated issues regarding competition in the satellite communications industry arise in both the domestic and international contexts). 
failed to determine how to measure the benefits of its recommendations. Clearly, the benefits are measurable, but, ironically, the only benefit quantified in the report involves the transfer of lawyer training courses back to Washington. ${ }^{19}$ Surely, the only recommendation that explicitly calls for savings should not be one involving lawyers.

Measurement techniques are available for at least some of the other recommendations. For example, those related to streamlining the rulemaking process ${ }^{20}$ ought to yield estimates of savings based on the time spent by the parties involved and the timeliness of the rules that result. It is also possible to compare the cost and time savings of regulatory negotiation ("reg neg") ${ }^{21}$ with those of "contested" rulemaking, including the implicit costs of judicial review. Admittedly, these numbers would be soft, but they would be more persuasive than no numbers at all. We live, after all, in an era of regulatory impact statements mandated by Congress and the Office of Management and Budget (OMB). If the value of lives can be quantified, then so can the savings in decisionmaking due to regulatory negotiation.

Moreover, other sections of the NPR Report have asserted high potential savings. For example, the report states that $\$ 4$ billion can be saved by improving the Social Security Administration (SSA) disability process. ${ }^{22}$ As one who has studied the SSA disability hearing process, ${ }^{23} \mathrm{I}$ am doubtful that a consensus can be built around a streamlining of that process. By claiming such a high potential savings, though, the reform effort may get the attention it needs. Similarly, an attempt to quantify the benefits of streamlined rulemaking might build support for the legislative and

19. The Justice Department has been required by statute to site legal education for government lawyers in Columbia, South Carolina. Merely returning this function to Washington would save $\$ 1.6$ million annually in travel and per diem costs. Interestingly, the regulatory systems report does not even recommend that this small amount be used to reduce the costs of government. Rather, it suggests that the savings be used to train nonlawyers. See IMPROVING REGULATORY SYSTEMS, supra note 11, at 69-72.

20. See id. at $41-46$.

21. Id. at 29-32.

22. This recommendation seeks to save $\$ 4$ billion by applying the "resources and management tools needed to reduce backlogs and to avoid paying benefits to individuals who are no longer disabled." NATIONAL PERFORMANCE REview, supra note 6, app. A at 141. These goals are worthy, undoubtedly, but hard to achieve.

23. See Jerry L. Mashaw et al., Social Security Hearings and Appeals (1978). 
agency changes necessary for such reform. Perhaps the best way to proceed at this stage is for the NPR staff, with assistance from the regulatory systems team, or even the ACUS, to undertake the quantification effort as a follow-up study, especially in areas in which Congress will be asked to implement change.

The regulatory systems report also suggests important regulatory alternatives that are susceptible to quantification. The ranking of risks, through improved risk analysis (listed as "REG07" in the report), ${ }^{24}$ and improvements in the use of regulatory science $(\mathrm{REG08})^{25}$ are vital steps towards making regulations concerning safety and the environment more cost-effective. Moreover, by encouraging more innovative approaches to regulation (REG02), ${ }^{26}$ the report reveals its sensitivity to the costs government imposes on the private sector. Command and control regulations often waste government and private resources. In almost every case, government-supervised, market-based initiatives can deliver more at less cost. ${ }^{27}$

\section{Politics AND the Corporate-Government ANALOGY}

The regulatory systems report's last sections address improving agency/Congress relationships (REG09) ${ }^{28}$ and providing better incentives and training for regulators (REG10) ${ }^{29}$ It is difficult to argue with these goals, and the report treats them as almost afterthoughts. The rest of this Comment explores the assumptions of these sections, because within them lies the key to answering the only question that matters: Can government be made more efficient?

24. IMPROVING REgULATORY SYSTEMS, supra note 11, at 53-57.

25. Id. at $59-63$.

26. Id. at $23-28$.

27. See Susan Rose-Ackerman, Consensus Versus Incentives: A Skeptical Look at Regulatory Negotiation, 43 DUKE L.J. 1206, 1212-16 (noting the advantages of incentive systems in regulation). Oddly, the report seems to justify command and control in certain cases "where risks that would result from noncompliance are high, as in the regulation of nuclear power." IMPROVING REGULATORY SYSTEMS, supra note 11, at 24. Given that the potential danger to the public in areas that the EPA regulates can be far greater than that from nuclear power that is regulated by the Nuclear Regulatory Commission, it makes little sense to single out nuclear power for command and control regulations while leaving other sources of power, such as coal, free to be regulated by market alternatives.

28. IMPROVING REGULATORY SYSTEMS, supra note 11, at 65-68.

29. Id. at 69-73. 
It is conceivable that government is indeed institutionally impervious to reform. Support for this hypothesis comes from several quarters, including those who decry the organizational paralysis that the political system of separation of powers and federalism produces ${ }^{30}$ and the public choice school that predicts how bureaucrats and members of Congress will behave. ${ }^{31}$ These sources argue reasonably that people get the government they deserve and that efficiency reform is beyond our society's capabilities.

These arguments are not completely sound. At least two. factors suggest that internally driven reform can work in government. First, the deregulation movement itself is evidence of the potential for self-correction. If regulation is good for those who propose and administer it, how does deregulation take hold? It is possible that the bipartisan congressional and executive combination of altruism and good sense that led to airline, motor carrier, railroad, and energy deregulation could be mustered again toward the more general goal of government efficiency. Second, American businesses, even monolithic and internally focused organizations like Ford and IBM, are reforming themselves through quality management. They, like Xerox, ${ }^{32}$. were targeted for oblivion by foreign competition and have come back from the dead. Why can government-at all levels, but especially at the federal level-not do the same?

One obvious answer is that government is not private enterprise. When a corporation is failing, it gets clear signals from the market. Recent successful corporate turnarounds have been founded on reaction to these signals by management and boards of directors. CEOs in this environment are no longer sacrosanct, as the former CEOs of Westinghouse, Kodak, and IBM can testify. ${ }^{33}$ They are increasingly challenged by their boards, and boards are

30. See, e.g.; Lloyd N. Cutler, To Form a Government, in SEPARATION OF PowERS-DOES IT STILL WORK? 1 (Robert A. Goldwin \& Art Kaufman eds., 1986) (arguing that the original justifications for the separation of powers are no longer valid).

31. See generally James M. Buchanan \& GoRdon Tullock, THE Calculus of CONSENT (1962) (arguing that the structure of government reflects the rational economic choices of individual constituents).

32. See David T. Kearns \& David A. Nadler, Prophets in the Dark: How XEROX REINVENTED ITSELF AND BEAT BACK THE JAPANESE (1992) (chronicling how the company reinvented itself by emphasizing quality).

33. See Bigger They Are, Harder They Fall: '93 Tough Year For Executives, CleveLAND PLAIN DEALER, Jan. 2, 1994, at E1. 
in turn challenged by more active stockholders, especially pension funds. Government, on the other hand, does not receive market signals when it is failing, ${ }^{34}$ and it has no CEO or board to make firm decisions. There are close enough resemblances, though, to make it possible to view government from a business perspective.

Although government cannot fail in the corporate sense, its performance certainly can be measured. The cost-plus mentality of expanding the functions of government without regard to budgets is a thing of the past. Some state governments are taking innovative steps to measure the performance of government programs. In Oregon, for example, citizens measure programs against national benchmarks. ${ }^{35}$ States generally have been making innovative market-oriented decisions that have been labelled "reinventing government." ${ }^{36}$ Moreover, not-for-profit corporations, which do not have traditional bottom-line concerns, also are developing creative ways to measure performance. ${ }^{37}$ One of the most successful companies in the insurance field, for example, is USAA, a not-for-profit corporation. The American Automobile Association (AAA) also is not-for-profit, but it has been working to develop new ways to measure performance that emulate the market of forprofit competitors. By adopting a concept of internal "customers" and by benchmarking best practices, AAA has set measurable

34. Public choice theory has introduced the concept of government failure, which is analogous to market failure. See BUCHANAN \& TULLOCK, supra note 31, at 3-9; Charles K. Rowley, Market "Failure" and Government "Failure", in THE ECONOMICS OF POLITICS 29, 31 (1978). In Florida, the governor recently issued a report that states without equivocation that "government in America is failing." 1 GOVERNOR'S COMMISSION FOR GOVERnMent By THE PEOPLE: A PRESCRIPTION FOR FloridA's Future 3 (1991).

35. The Oregon approach measures the performance of key programs, such as crime control, taxes, and child care against the performance of other states. North Carolina has created a private commission to do the same. See Rob Christensen, How Good Is Government? New Group to Set Standard, Raleigh NEwS \& OBSERver, Jan. 21, 1974, at 1A. Although comparisons with other states are useful, the best benchmarks may lie outside government altogether.

36. See David E. Osborne \& Ted GaEbler, ReINVENTING Government: How the Entrepreneurial SpIRIT is Transforming the Public Sector (1992). David Osborne was a speech writer for President Clinton during the campaign and is the editor of the NPR Report.

37. The not-for-profit sector in the United States contains many huge companies and is not often studied for the lessons it can offer government or vice versa. Research into these companies could be very beneficial. In addition, large regulated entities like public utilities are becoming increasingly competitive. See, e.g., Charles R. Moyer, The Impending Restructuring of the Electric Utility Industry: Cause and Consequences, BUS. ECON.. Oct. 1993, at 40 (discussing the effect of deregulation on electricity companies). The era of cost-plus rulemaking, which insulated these companies from market forces, is over. 
goals for worker performance. In sum, there are plenty of models for the federal government to employ in measuring its performance. ${ }^{38}$

Government is not the only entity seeking new models to imitate. A fascinating development in the corporate world is the borrowing of innovative ideas from unlikely sources, at the same time that government and the not-for-profit sector are considering market-driven approaches. Charles Handy has argued that corporations should borrow organizational principles from government and become more "federalist" in nature. ${ }^{39} \mathrm{He}$ even argues that business could benefit from the principle of separation of powers. ${ }^{40}$ Undoubtedly, successful corporations are decentralizing ("federalizing") to achieve economy and flexibility. IBM is the latest example of a highly centralized organization splitting into smaller, lightly directed units. ${ }^{41}$ Given this trend, the much-maligned system of federalism seems to be gaining new respect. ${ }^{42}$

The other reason that government cannot duplicate the success of private sector reforms involves management and governance. Corporations are ultimately responsible to stockholders, as government is to citizens, but they are managed and governed by CEOs and boards who resemble the President and Congress only slightly. The problem with government is that no one is really held responsible for government performance. The Washington game, at least when the branches are politically divided, is for Congress to blame the executive and vice versa. On many occasions, gridlock seems to be the considered policy option.

38. In fairness to the NPR, its goal is for the federal government to emulate innovative companies. The NPR Report mentions putting customers first. empowering employees, and producing better government for less-goals that are shared by the private sector in the search for total quality management. NATIONAL PERFORMANCE REVIEW, supra note 6 , at 6-7; see infra note 56 (discussing total quality management).

39. See Charles Handy, Balancing Corporate Power: A New Federalist Paper, HARv. BuS. REV., Nov.-Dec. 1992, at 59, 59-61.

40. Handy suggests that management, monitoring, and governance-the corporate equivalent of the executive, judicial, and legislative branches-should be unsegregated. Id. at 67 . One wonders if corporations truly want to replicate the counter-efficiency virtues of the system of separated powers.

41. See Steve Lohr. I.B.M. May Abandon its Hilltop Headquarters, N.Y. TIMES, Jan. 13. 1994, at A1 (outlining IBM's plan to decentralize and streamline management).

42. Alice Rivlin, President Clinton's Deputy Director of OMB, also has argued for a revival of federalism. See ALICE M. RIVLIN, REVIVING THE AMERICAN DREAM 110-25 (1992). 
In an ideal world where the President manages and Congress sets policy, the corporate analogy might work. As a practical matter, however, neither branch is willing to view its role in such dichotomous terms, especially Congress, which not only sets policy but wants to enforce it as well. For example, Congress often makes statutory assignments to specific agencies, even some labelled "independent" of the executive, and then conducts extensive oversight hearings. This kind of extreme micromanagement would make most corporate boards blush. ${ }^{43}$ For its part, the executive branch not only manages, but the President also pursues an independent policy role, especially with regard to foreign affairs.

Given these political realities, it is probably pointless to push the corporate governance analogy too far. It might work better with a different constitutional framework. ${ }^{44}$ Nevertheless, few would argue with the proposition that if Congress could be motivated to leave the execution of policy to the executive, government would be more efficient. If Congress and the President worked together to create a strategic plan for the government, there might be some clear gains in productivity. Indeed, if the two branches could plan together with a long-term view, ${ }^{45}$ these gains miglit even change the nature of the relationship between the branches.

43. See generally Sidney A. Shapiro, Political Oversight and the Deterioration of Reg. ulatory Policy, 46 ADMIN. L. REV. 1, 4, 24-26 (1994) (viewing the oversight struggle between Congress and the President as a negative-sum game and documenting examples of micromanagement by both branches).

44. The parliamentary system, for example, allows executive officials to be part of the legislature and thereby places fewer formal restrictions on performance. Cabinet members are part of the legislative process, and the civil service is a permanent bureaucracy with .more credibility than America's. See Thomas O. Sargentich. The Limits of the Parliamentary Critique of the Separation of Powers, 34 WM. \& MARY L. REv. 679 (1993) (defending our system of separation of powers against challenges from the parliamentary model). The same is true in France, where the Conseil d'Etat is the equivalent of an administrative government. It runs the bureaucracy and draws its employees from the most prestigious universities. In fact, the regulatory systems report refers to this organization indirectly by accepting Judge Stephen Breyer's suggestion that a high-quality training program for a "special group" of fast-track civil servants might be desirable. See IMPROVING REgulatory SYSTEMS, supra note 11. at 69; STEPHEN BREYER, BREAKING THE Vicious CiRCle: TOWARD EFFECTIVE RISK REgulation 64-81 (1993).

45. The NPR Report advocates a biennial budget process, which is a step in the right direction. See National Performance Review, supra note 6, at 16-17. 


\section{THE PROMISE OF THE GPRA}

The Government Performance and Results Act of 1993 (GPRA), ${ }^{46}$ a remarkable piece of legislation, suggests that this potential rapprochement of the branches is not just wild speculation. It introduces the requirement of performance-based budgeting by expanding on an earlier act that sought to improve financial management activities within the federal government. ${ }^{47}$ The GPRA is unusual both in how it emerged politically and in its promise of radical reform at the level of strategic planning for government agencies. It is one of the few congressional directives in this realm that has the full support of $O M B$ and the executive branch. ${ }^{48}$ Its stated purposes are consistent with those of the NPR. ${ }^{49}$ Among them is to "improve Federal program effectiveness and public accountability by promoting a new focus on results, service quality, and customer satisfaction." 50

The Act has two phases. First, it requires at least ten executive agencies to establish pilot programs in performance measurement for the fiscal years 1994, 1995, and 1996. ${ }^{51}$ Each year, the agencies must prepare plans that set measurable performance goals and then issue a report that compares actual performance with these goals. ${ }^{52}$ Thereafter, subject to OMB providing Congress

46. Pub. L. No. 103-62, 107 Stat. 285 (1993) (to be codified in scattered sections of 5 U.S.C., 31 U.S.C., and 39 U.S.C.). For background on the history and purpose of the Act, see S. REP. No. 58, 103d Cong., 1st Sess. (1993), reprinted in 1993 U.S.C.C.A.N. 327.

47. See Chief Financial Officers Act of 1990, 31 U.S.C. $\S 501$ (Supp. IV 1992).

48. See S. REP. No. 58, 103d Cong., 1st Sess. 7 (1993), reprinted in 1993 U.S.C.C.A.N. 327, 329 (statement of OMB Director Leon Panetta).

49. Although the Act reflects the goals set out in the NPR, it is not a product of the White House. Indeed, its genesis seems to be in congressional frustration with agency performance, in particular the Department of Housing and Urban Development scandal of a few years ago involving the embezzlement of more than $\$ 5$ million from the agency between 1985 and 1988. See id, at 7, reprinted in 1993 U.S.C.C.A.N. 327, 333 (remarks of Florida Senator Bob Graham). In addition, the Government Accounting Office (GAO) and the National Academy of Public Administration (NAPA) were strong supporters. Id. at 3-5, 8-9, reprinted in 1993 U.S.C.C.A.N. at 29-31, 334-35 (remarks of Comptroller General Charles A. Bowsher and Richard A. Wegman of NAPA). The Act also was supported by the conclusions of a 1992 GAO study. See GoverNMENT ACCOUNTING OFfice, Program Performance Measures: Federal agency Collection and Use OF PERFORMANCE DATA (1992).

50. GPRA \& 2(b)(3), 107 Stat. at 285.

51. Id. $\$ 1118,107$ Stat. at 290.

52. Id. $\S 1116,107$ Stat. at 288 . The director of OMB has already issued a request for agencies to participate in this exercise. See Memorandum from Leon E. Panetta to 
with a positive review of the programs, OMB would be required to submit, beginning in fiscal year 1999, a Federal Government Performance Plan as part of the annual budget. ${ }^{53}$ The Act provides that during the pilot stage, and periodically thereafter, the agencies could seek waivers of nonstatutory procedural requirements and controls in return for increased managerial flexibility. In subsequent years, agencies would be selected to engage in performance budgeting. ${ }^{55}$

The GPRA is a creative and pro-business approach to the bureaucracy. It applies the principles of total quality management ${ }^{56}$ which have guided business over the last decade, to government. To establish strategic plans and set performance goals over a five-year period requires a sustained level of planning and execution of which many think government is not capable. The idea of Congress and the executive that performance budgeting could work for the federal budget process as a whole is a radical one. If it succeeds, the notion of government behaving like a business organization will no longer be fanciful.

By establishing a five-year planning process, the Act contemplates that executive agencies will transcend the term of a single presidency. It may be unrealistic to imagine that performance budgeting can survive such political pressures. The Senate Report seeks to meet this objection: "Even when a change in Administration brings about a shift in political philosophy, the program's missions and long-term general goals remain largely intact. The priorities and means of aclieving those goals, and the approach to problein solving, may vary significantly, but the long-term goals usually remain the saine."

Heads of Executive Departments and Agencies (Oct. 8, 1993).

53. GPRA § 1105(a), 107 Stat. at 286. The GPRA also requires the U.S. Postal Service to submit a strategic plan to Congress by 1997 and to establish goals and program performance reports. Id. $\$ \S 2802-2803,107$ Stat. at 292-93.

54. Id. $\$ 9703,107$ Stat. at 289 . Waivers of procedural requirements would allow for compensation set above prescribed levels and even bonuses for performance. See id. $\S$ 9703(c).

55. GPRA § 1119, 107 Stat. at 291.

56. Total quality management is a process whereby quality is built-in, not inspected for afterwards, and in which the needs of the customer dictate business decisions. Its creator and patron saint is the late W. Edwards Deming, who initially had more success with the process in Japan than in the United States. See RAFAEL AguaYo, DR. Deming: The American who Taught the Japanese About Quality (1990). See generally Verkuil, supra note 7, at 13-14 (discussing how U.S. businesses woke up to Deming's message).

57. S. REP. No. 58, 103d Cong., 1st Sess. 15 (1993), reprinted in 1993 U.S.C.C.A.N. 
This statement certainly takes a benign view of the political process. It seemingly ignores the political reality that Presidents like to control the agencies, even in areas where Congress has carved out a long-term interest. Moreover, political appointees of a new President often have their performance measured precisely by how well they can derail agency programs disfavored during the campaign. Still, this is not an act passed by a naive Congress. It was originally proposed during the Bush administration ${ }^{58}$ and now has bipartisan congressional support. President Clinton has assigned an enthusiastic OMB to implement it, and the NPR is an endorsement of its message..$^{59}$ It is possible that with such broadbased support, the effective management of government can permanently turn the corner from theory to reality. ${ }^{60}$

It will take the full support of the bureaucracy for this transformation to occur. There are statutory incentives in place to help win bureaucratic acceptance. The first is the acknowledgement that, as in the quality management of corporations, work must be taken out of the process as well as put in so as not to exhaust agency resources and personnel. ${ }^{61}$ Indeed, the very purpose of strategic planning, goal setting, and performance results is to align resources with mission. This news should hearten an often beleaguered bureaucracy. A second inducement to obtaining agency cooperation is the availability of managerial flexibility waivers that would allow for the exercise of procedural discretion in shifting resources to different projects within the agency to the extent that improved substantive results are achieved. ${ }^{62}$ Results, not compliance with rigid mandates, are the goal.

$327,341$.

58. The GPRA originally was introduced by Senator Roth of Delaware on Oct. 3 . 1990, as the Federal Program Performance Standards and Goals Act of 1990. Id. at 348.

59. David Osborne, who coauthored the NPR Report, also testified in favor of the GPRA. Id. at 349.

60. Still to be resolved is what might be called the "oversight fight" between Congress and the executive. If Congress can restrain itself and measure agency compliance with the management goals contained in the GPRA, then change can occur; if agency oversight remains an episodic and political publicity arena, it will continue to be business as usual. See Shapiro. supra note 44, at 19-26 (discussing the negative consequences for agency efficacy produced by the "oversight game").

61. The Senate Report similarly cautions against the "hollow government" phenomenon, in which inadequate resources are allocated to expanding public missions. S. REP. No. 58. 103d Cong., 1st Sess. 16 (1993), reprinted in 1993 U.S.C.C.A.N. 327, 342.

62. See id. at $343-44$. 
Unfortunately, the Act does not go far enough. By exempting matters of statutory compulsion from managerial flexibility waivers, it leaves in place many counterproductive regulatory restraints. Perhaps agency proposals for statutory modifications could be encouraged by a reform-minded Congress. Moreover, the Act does not authorize the waiver of "statutory provisions or regulations promulgated under the Administrative Procedure Act." ${ }^{163}$ By acknowledging that the requirements of the Adminstrative Procedure Act are beyond the agencies' managerial waiver power, we have come full circle.

Notwithstanding these shortcomings, the creative initiatives on rulemaking and procedural reform advocated by the regulatory systems report, most of which do not require statutory change, ${ }^{64}$ are still quite relevant to the grander goals of the GPRA and the NPR. The Act, supplemented by useful, if not dramatic, procedural variations suggested in the regulatory systems report, is an innovative scheme for rethinking government organization along successful business lines. All in all, the NPR report and the regulatory systems report deserve support both in and out of government.

\section{CONCLUSION}

The regulatory systems report is a relatively unexceptional part of a larger program for regulatory reform-the National Performance Review-that does make bold proposals for change. Even the NPR, though, pales in comparison to the potentially radical reform possibilities of the Government Performance and Results Act of 1993. This little-noticed legislative inducement to change the management goals, incentives, and outcomes of federal agencies bears careful watching and deserves full support. ${ }^{65}$ In the popular jargon of the corporate world, the GPRA intends no less than to change the management "culture" of the federal government. By becoming more entrepreneurial, creative, and flexible, government agencies can become more "productive," a term that must be quantified for government or business to succeed. The

63. Id. at 344 .

64. See IMPROVING REgULATORY SySTEMS, supra note 11, at 23-46.

65. Indeed. one of the future projects of this Journal's administrative law issue might be to track agency compliance with the GPRA. A sustained, public review of its promise and achievements can do much to ensure its success. 
question that titles this Comment remains unanswered, but at least there is a framework in place for seeking the answer, which is a qualified "no." Government can become efficient but not in the same way that business can. Government efficiency requires a political commitment that must be total and sustained. The NPR provides a stage upon which this exercise can begin. 